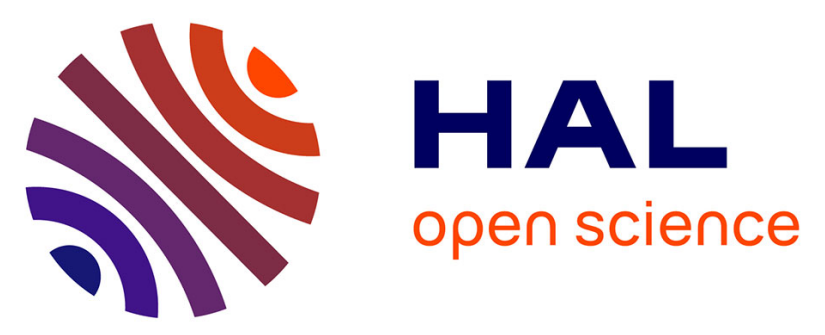

\title{
Effects of human insulin-like growth factor-1 on the release of growth hormone by rainbow trout (Oncorhynchus mykiss) pituitary cells
}

\author{
J. Perez-Sanchez, Claudine Weil, Pierre-Yves Le Bail
}

\section{- To cite this version:}

J. Perez-Sanchez, Claudine Weil, Pierre-Yves Le Bail. Effects of human insulin-like growth factor-1 on the release of growth hormone by rainbow trout (Oncorhynchus mykiss) pituitary cells. Journal of Experimental Zoology, 1992, 262, pp.287-290. 10.1002/jez.1402620308 . hal-02713574

\section{HAL Id: hal-02713574 \\ https://hal.inrae.fr/hal-02713574}

Submitted on 1 Jun 2020

HAL is a multi-disciplinary open access archive for the deposit and dissemination of scientific research documents, whether they are published or not. The documents may come from teaching and research institutions in France or abroad, or from public or private research centers.
L'archive ouverte pluridisciplinaire HAL, est destinée au dépôt et à la diffusion de documents scientifiques de niveau recherche, publiés ou non, émanant des établissements d'enseignement et de recherche français ou étrangers, des laboratoires publics ou privés. 


\title{
Effects of Human Insulin-Like Growth Factor-I on Release of Growth Hormone by Rainbow Trout (Oncorhynchus mykiss) Pituitary Cells
}

\author{
J. PÉREZ-SÁNCHEZ, C. WEIL, AND P.-Y. LE BAIL \\ Inst. Acuicultura, CSIC, 12595 Torre de la Sal, Castellón, Spain (J.P.-S.) \\ and Lab. Physiologie des Poissons, INRA, Campus de Beaulieu, 35042 \\ Rennes Cedex, France (C.W., P.-Y.L.B.)
}

\begin{abstract}
A recombinant human IGF-I (rhIGF-I) was applied to primary cultures of rainbow trout pituitary cells. In wells containing $3 \times 10^{4}$ and $6 \times 10^{4}$ cells/well, rhIGF-I inhibited basal GH release both in short $(6 \mathrm{~h})$ and long $(12$ and $24 \mathrm{~h}$ ) exposures. The decline in $\mathrm{GH}$ release was dosedependent over the range of 0.01 and $100 \mathrm{mM}$. The combination of rhIGF-I and low concentrations of synthetic somatostatin s $_{14}$ (SRIF) enhanced the inhibitory effect of rhIGF-I in an additive manner. Any appreciable effect of rhIGF-I on PRL release was not evidenced. To our knowledge, this report demonstrates for the first time the participation of IGFs on the inhibitory component of fish GH regulation. $\mathcal{O} 1992$ Wiley-Liss, Inc.
\end{abstract}

In fish as in other vertebrate species, the release of growth hormone $(\mathrm{GH})$ appears to be regulated by two hypothalamic neuropeptides, the inhibitory somatostatin (SRIF) (Fryer et al., '79; Cook and Peter, '84, '86; Marchant et al., '87; Luo et al., '90; Le Bail et al., '91) and the stimulatory growth hormone-releasing factor (GRF) (Luo and Mckeown, '89; Luo et al., '90; Le Bail et al., '91). There are, however, other metabolic factors that interact at the central level and contribute to establishing the control of pituitary GH release. Thus a variety of in vivo (Abe et al., '83; Tannenbaum et al., '83) and in vitro (Berelowitz et al., '81; Brazeau et al., '82; Goodyer et al., '84; Yamashita and Melmed, '86; Lamberts et al., '89) systems have shown that the insulin-like growth factors (IGFs), defined as the mediators of the somatogenic action of GH (Daughaday et al., '72), inhibit GH release by mammalian pituitary cells.

Serum IGF-I activity has been detected in rainbow trout (Oncorhynchus mykiss) (Daughaday et al., '85), Atlantic salmon (Salmo salar) (Lindahl et al., '85), tilapia (Oreochromus mossambicus) (Drakenberg et al., '89), and sea bream (Sparus aurata) (Funkenstein et al., '89) using radioimmunoassays (RIAs) or placental radioreceptor assays (RRAs) for mammalian IGF-I. Cao et al. ('89) have obtained the cDNA sequence encoding preproIGF-I from coho salmon (Oncorhynchus kisutch), evidencing that the primary structure of IGF-I is highly conserved in relation to its mammalian homologues. In addition, it has been observed that IGFs can mediate the stimulatory action of GH on the sulfate uptake by trout (Komourdjian and Idler, '78) and Japanese eel (Duan and Hirano, '90; Duan and Inui, '90) cartilage. It has also been demonstrated that GH treatment increases IGF-I mRNA levels in coho salmon and serum IGF-I immunoreactivity in sea bream (Funkenstein et al., '89). However, whether IGFs participate on the regulation of fish $\mathrm{GH}$ release remains unexplored. The present study demonstrates a selective and dose-dependent IGF-I inhibition of basal GH secretion by pituitary cells of rainbow trout, delineating the participation of IGFs on the negative feedback loop of $\mathrm{GH}$ release.

\section{MATERIALS AND METHODS}

Animals. Studies were carried out on 1-year-old (90-130 g weight) rainbow trout (purchased from the INRA Gournay fish farm, France) kept at $15^{\circ} \mathrm{C}$ in a recirculating water system under a $15 \mathrm{~h}$ light: $9 \mathrm{~h}$ dark photoperiod.

Test agents. Recombinant human IGF-I (rhIGFI) was kindly provided by Ciba-Geigy. Synthetic somatostatin ${ }_{14}$ (SRIF) was offered generously by Sanofi.

Cell culture. Pituitary glands from 200 immature fish were removed, submitted to collagenase dispersion, and cultured according to the method of Weil et al. ('86). After 3 days of culture in 96-well

Received May 8, 1991; revision accepted October 18, 1991. 
plates (NUNC) at $18^{\circ} \mathrm{C}$, pituitary cells were washed twice with RPMI medium (GIBCO Laboratories), containing Hepes $(20 \mathrm{mM})$ and $\mathrm{NaHCO}_{3}(9 \mathrm{mM})$ ( $\mathrm{pH}=7.5$; osmotic pressure $=300 \mathrm{mOsm} / \mathrm{Kg}$ ). Subsequently, pituitary cells were reincubated in this medium with or without test agents (rhIGF-I, SRIF). Test incubations lasted from 6 to $24 \mathrm{~h}$. At the end of incubation time, well plates were centrifuged at $200 \mathrm{~g} \times 10 \mathrm{~min}$, the medium was removed, diluted (1:100) in hormone-assay buffer containing BSA (1\%), and frozen for later homologous salmon $\mathrm{GH}$ (Le Bail et al., '91) and salmon prolactin (Prunet et al., '85) RIAs. A nonparametric test (KolmogorofSmirnov) was used for statistical evaluation of cell culture results.

\section{RESULTS}

In wells containing $3 \times 10^{4}$ and $6 \times 10^{4}$ cells $/$ well, the secretion of $\mathrm{GH}$ into the medium increased progressively during the 24-h time course of incubations (Fig. 1). In both density conditions, addition of rhIGF-I ( $10 \mathrm{nM})$ to the medium caused a significant decrease in basal GH secretion both in short $(6 \mathrm{~h})$ and long ( 12 and $24 \mathrm{~h}$ ) exposures. As rhIGF-I may exert its action on $\mathrm{GH}$ secretion by a nonselective suppression of pituitary hormone release,

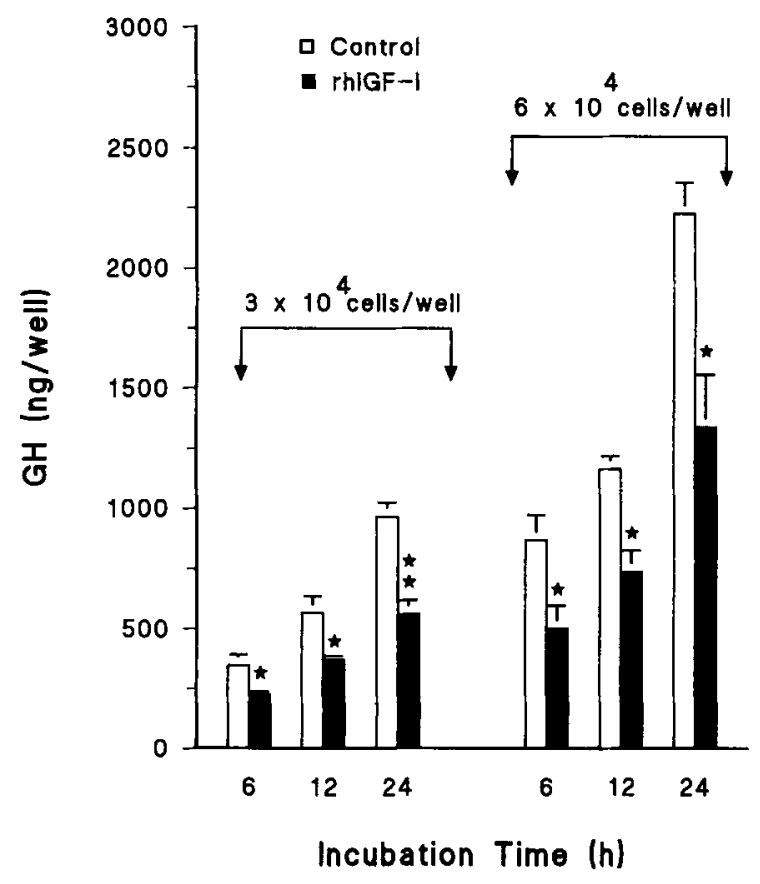

Fig. 1. Effects of cell density and duration of incubation on $\mathrm{GH}$ release in response to rhIGF-I ( $10 \mathrm{nM})$ by cultured rainbow trout pituitary cells. Each value represents the mean and standard error of three or four replicates. $(P<0.05),(P<0.01)$; significant differences in relation control values. we also measured the levels of PRL into the culture medium. The results showed that rhIGF-I (10 nM) did not alter basal PRL secretion by trout pituitary cells (Fig. 2).

Figure $3 \mathrm{~A}$ shows that the 6 -h treatment with rhIGF-I inhibits basal GH secretion $\left(3 \times 10^{4}\right.$ cells/ well) in a dose-dependent fashion. This decline in GH secretion was significant when cultured cells were exposed to concentrations of $1 \mathrm{nM}(P<0.05)$ and higher $(P<0.01)$. The maximal inhibitory concentration (100-300 $\mathrm{nM}$ ) inhibited GH release by $50 \%$. A significant suppressive effect of SRIF on GH release was also observed when cultured cells were exposed to concentrations of $0.03 \mathrm{nM}(P<0.05)$. The maximal SRIF concentration (100 $\mathrm{nM})$ achieved an inhibitory value of $80 \%$. $(P<0.01)$. This suppressive effect was more powerful than that exerted by rhIGF-I at equimolar concentrations. Figure 3B shows that the combination of rhIGF-I (1-10-100 $\mathrm{nM})$ and low concentrations of SRIF (0.1 nM) enhanced the inhibitory effect of rhIGF-I in a strictly additive manner.

\section{DISCUSSION}

The present study demonstrates IGF inhibition of $\mathrm{GH}$ release by trout pituitary cells maintained in culture. Experiments were conducted on day 3 after initial plating, when the majority of cells (3-6 $\times 10^{4}$ cells/well) appeared firmly attached to wells as Weil et al. ('86) previously described. In these

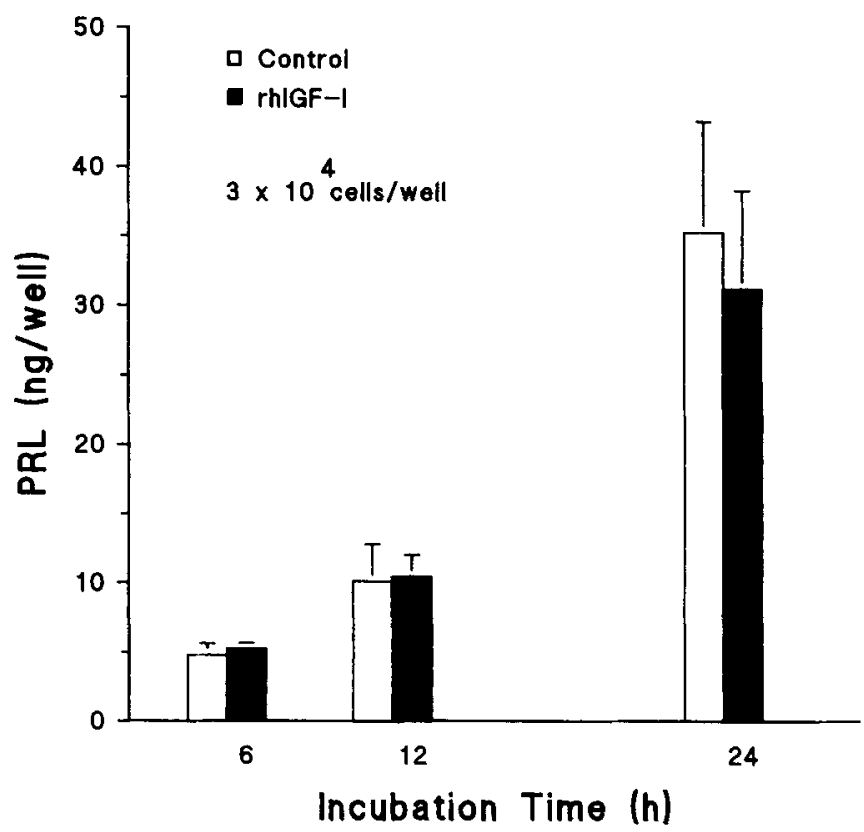

Fig. 2. Effect of duration of incubation on PRL release in response to $\mathrm{rhIGF}-\mathrm{I}(10 \mathrm{nM})$ by cultured rainbow trout pituitary cells. Each value represents the mean and standard error of three or four replicates. 


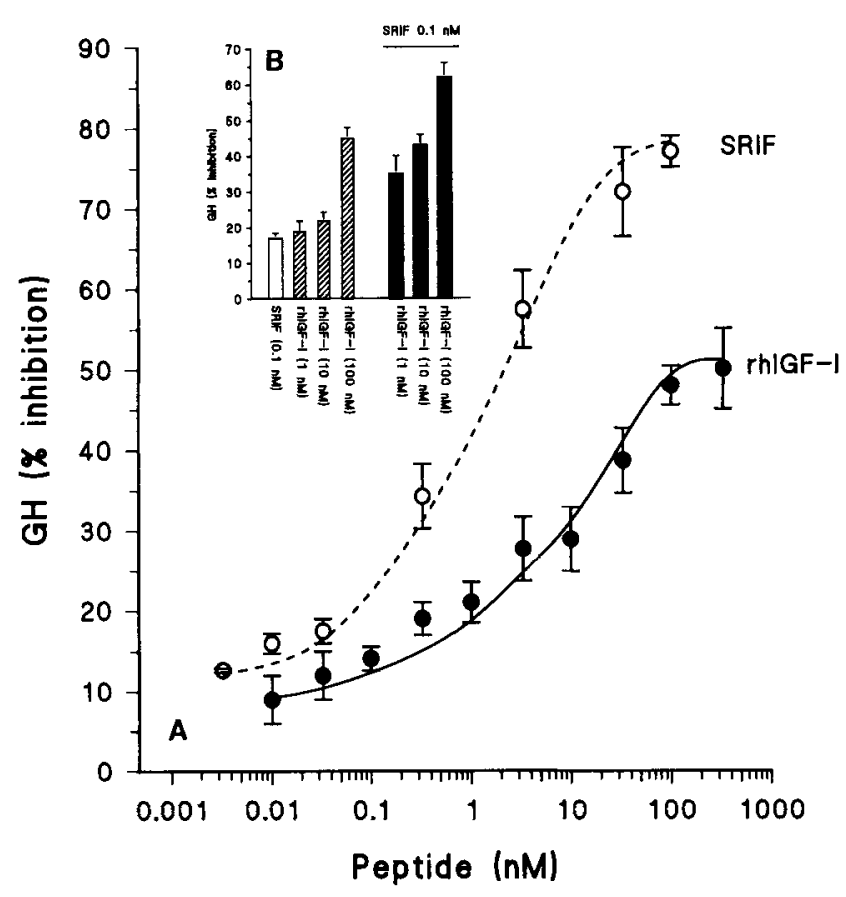

Fig. 3. A. Dose-dependent curve of the effect of rhIGF-I and SRIF on secretion of $\mathrm{GH}$ by cultured rainbow trout pituitary cells $\left(3 \times 10^{4}\right.$ cells $/$ well $)$ after 6 -h incubation period. $B$. The inset shows the effect on GH release of combined concentration of rhIGF-I and SRIF. Each value represents the mean and standard error of four or five replicates.

culture conditions, rhIGF-I inhibited basal trout GH release both in short and long exposures, in a similar manner as it has been reported for basal and GRF-stimulated rat $\mathrm{GH}$ release (Yamashita and Melmed, '86). Brazeau et al. ('82) have also reported that a highly purified mammalian IGF-I decreases rat GRF-stimulated GH release in both 4- and 24-h treatments, whereas Berelowitz and coworkers ('81) only found a chronic effect. Conversely, Goodyer et al. ('84) reported that a semipurified preparation of IGF peptides decreases both basal and theophylline-stimulated $\mathrm{GH}$ release after a short exposure, but only extremely high concentrations are effective at $24 \mathrm{~h}$. Therefore, it appears clear that IGF-I can act directly on the pituitary to inhibit GH release, but the dynamics of IGF-I inhibition are contradictory probably due to differences in culture conditions.

Our results also indicate that the inhibition of trout GH release by a mammalian IGF-I occurs in a dose-dependent manner. Differences in IGF sequences between mammalian and fish species (see Cao et al., '89) can explain that the dose of half maximum effect $(3 \mathrm{nM})$ is relatively higher than those reported in primary cultures of rat pituitary cells. Although at equimolar concentrations, the maxi- mum inhibitory effect is comparable (Yamashita and Melmed, '86) and even higher (Lamberts et al, '89) than those observed in homologous mammalian systems. This fact supports the view that the IGF-I inhibition of trout GH release is of a physiological nature rather than a pharmacological one. In contrast, the inhibition of GH secretion, with no effect on PRL release, suggests that IGF action is not due to a nonspecific inhibition of pituitary hormone release. Earlier studies have evidenced the suitability of our culture system to inhibit basal PRL release (Le Goff, '90). Nevertheless, taking into account that the amount of PRL secreted in this and other pituitary fish culture systems (Suzuki et al., '87, '91) is markedly lower than the one of $\mathrm{GH}$, we cannot exclude the possibility that the inhibition of PRL by IGF preparations is more difficult to evidence than the $\mathrm{GH}$ one. To make things more confusing, controversial results have been reported in previous mammalian studies. Yasmahita and Melmed ('86) and Berelowitz and coworkers ('81) did not show any effect of IGFs on PRL release, whereas Goodyer et al. ('84) found an inhibitory action of a human blood IGF-I preparation on rat PRL release. However, as it has been suggested by Lamberts et al. ('89), this fact might be due to impurities of IGF preparation.

From a functional point of view, it is interesting to denote that our results also corroborate a SRIF dose-dependent suppression of fish $\mathrm{GH}$ release, evidencing an additive action of SRIF and rhIGF-I when both peptides were incubated on the same wells. Furthermore, as expected from the results obtained in mammals (see Lamberts et al., '89), SRIF inhibition of GH release is more powerful than that reported for a comparable amount of IGF-I, probably due to the fact that IGF-I inhibits preferentially the release of newly synthesized GH, whereas SRIF acts on both stored and recently synthesized hormone (Sheppard et al. '86).

From all these results, we can conclude that IGFs can act as an inhibitory component of fish GH regulation. This finding, together with the earlier observation that GH treatment increases IGF-I activity in fish species (Cao et al., '89; Funkenstein et al., '89), delineates the participation of IGFs on the negative feedback loop of GH release, in a similar manner as it has been reported for higher vertebrates.

\section{ACKNOWLEDGMENTS}

We thank Dr. P. Prunet for supplying RIA prolactin products and Dr. P. Swift (Ciba-Geigy) for supplying rhIGF-I. We are also grateful to Sanofi for supplying SRIF. 


\section{LITERATURE CITED}

Abe, H., M.E. Molitch, J.J. Van Wyk, and L.E. Underwood (1983) Human growth hormone and somatomedin $\mathrm{C}$ suppress the spontaneous release of growth hormone in unanesthetized rats. Gen Comp. Endocrinol., 113:1319-1324.

Berelowitz, M., M. Szabo, L.A. Frohman, S. Firestone, and L. Chu (1981) Somatomedin C mediates growth hormone negative feedback by effects on both the hypothalamus and the pituitary. Science, 212:1279-1281.

Brazeau, P.R., R. Guillemun, N. Ling, J. Van Wyk, and R. Humbel (1982) Inhibition par les somatomédines de la sécrétion de l'hormone de croissance par le facteur hypothalamique somatocrinine (GRF) ou le peptide de synthèse hpGRF. C.R. Séances Acad. Sci. Ser., 3:295-654.

Cao, Q-P., S.J. Duguay, E. Plisetskaya, D.F. Steiner, and S.J. Chan (1989) Nucleotide sequence and growth hormoneregulated expression of salmon insulin-like growth factor I mRNa. Mol. Endocrinol., 3:2005-2010.

Cook, A.F., and R.E. Peter (1983) The effects of somatostatin on serum growth hormone levels in the goldfish, Carrassius auratus. Gen. Comp. Endocrinol., 54:109-113.

Daughaday, W.H., K. Hall, M.S. Ruben, W.D. Salmon, J.L. Van de Brande, and J.J. Van Wyk (1972) Somatomedin: proposed designation for sulphation factor. Nature, 275:107.

Daughaday, W.H., M. Kapadia, C.E. Yanow, K. Fabrick, and I.K. Mariz (1985) Insulin-like growth factors I and II of nonmammalian sera. Gen. Comp., 59:316-325.

Drakenberg, K., V.R. Sara, K.I. Lindhal, and B. Kewish (1989) The study of insulin-like growth factors in tilapia, Oreochromus mossambicus. Gen. Comp. Endocrinol., 74:173-180.

Duan C., and T. Hirano (1990) Stimulation of ${ }_{35} \mathrm{~S}-$ Sulfate uptake by mammalian insulin-like growth factors I and II in cultured cartilages of the Japanese eel, Anguilla japonica. J. Exp. Zool., 256:347-350.

Duan C., and Y. Inui (1990) Effects of recombinant eel growth hormone on the uptake of ${ }^{35} \mathrm{~S}$-Sulfate by ceratobranchial cartilages of the Japanese eel, Anguilla japonica. Gen. Comp. Endocrinol., 79:320-325.

Fryer, J.N., R.S. Nishioka, and H.A. Bern (1979) Somatostatin inhibition of teleost growth hormone secretion. Gen. Comp. Endocrinol., 39:244-246.

Funkenstein, B., A. Silbergeld, B. Cavari, and Z. Laron (1989) Growth hormone increases plasma levels of insulin-like growth factor (IGF-I) in a teleost, the gilthead sea bream (Sparus auratus). J. Endocrinol., 120:R19-R21.

Goodyer, C.G., L. De Stephano, H.J. Guyda, and B.I. Posner (1984) Effects of insulin-like growth factors on adult male rat pituitary function in tissue culture. Endocrinology, 115: 1568-1576.

Komourdjian, M.P., and D.R. Idler (1978) Hepatic mediation of hormonal and nutritional factors influencing the in vitro sulfur uptake by rainbow trout bone. Gen. Comp. Endocrinol., $36: 33-39$.

Lamberts S.W.J., F. Den Holder, and L.J. Hofland (1989) The interrelationship between the effects of insulin-like growth factor I and somatostatin on growth hormone secretion by normal rat pituitary cells. The role of glucorticoids. Endocrinology, 124:905-911.

Le Bail, P.Y., J.P. Sumpter, J. Carragher, B. Mourot, P.D. Niu, and C. Weil (1991) Development and validation of high sensitive radioimmunoassay to chinook salmon (Oncorhynchus tshwaytscha) growth hormone. Gen. Comp. Endocrinol., 83:75-85.

Le Goff, P. (1990). Contribution á l'étude du contròle de la sécrétion de prolactine et de l'expression de ce gène chez la truite arc-en-ciel (Oncorhynchus mykiss). Ph.D. thesis. University of Rennes, U.F.R. Sciences de la Vie et de l'Environnement.

Lindhal, K.L., V. Sara, G. Fridberg, and T, Nishimiya (1985) The presence of somatomedin in the Baltic salmon, Salmo salar, with special reference to smoltification. Aquaculture, 45:177-183.

Luo, D., and B.A. Mckeown (1989) An antioxidant dependent in vitro response of rainbow trout (Salmo gairdneri) somatotrophs to carp growth hormone-releasing factor (GRF). Horm. Metab. Res., 21:690-692.

Luo, D.A., B.A. Mckeown, J. Rivier, and W. Vale (1990) In vitro response of rainbow trout (Onchorhynchus mykiss) somatotrophs to carp hormone-releasing factor (GRF) and somatostatin. Gen. Comp. Endocrinol., 80:288-298.

Marchant, T.A., R.A. Fraser, P.C. Andrews, and R.E. Peter (1987) The influence of mammalian and teleost somatostatins on the secretion of growth hormone from goldfish (Carrasius auratus) pituitary fragments in vitro. Regul. Pept., 17:41-52.

Prunet, P., G. Boeuf, and L.M. Houdebaine (1985) Plasma and pituitary prolactin levels in rainbow trout during adaptation to different salinities. J. Exp. Zool., 235:187-196.

Sheppard, M.S., and R.M. Bala (1986) Cycloheximide blocks insulin-like growth factor I but not somatostatin inhibition of growth hormone secretion. Can. J. Physiol. Pharmacol., 65:515-519.

Suzuki, R., T. Kaneko, and T. Hirano (1991) Effects of osmotic pressure on prolactin and growth hormone secretion from organ-cultured eel pituitary. J. Comp. Physiol. B, 161:147-153.

Suzuki, R., M. Kishida, T. Ogasawara S. Hasegawa, and T. Hirano (1987) Prolactin and growth hormone secretion during long term incubation of the pituitary pars distalis of mature chum salmon, Oncorhynchus keta. Gen. Comp. Endocrinol., 68:76-81. Tannenbaum, G.S., H.J. Guyda, and B.I. Posner (1983) Insulinlike growth factors: a role in growth hormone negative feedback and body weight regulation via brain. Science, 220:77-79. Weil, C., P. Hansen, D. Hyam, F. Le Gac, B. Breton, and L. W. Crim (1986) Use of pituitary cells in primary culture to study the regulation of gonadotropin hormone $(\mathrm{GtH})$ secretion in rainbow trout: Setting up and validation the system as assessed by its responsiveness to mammalian gonadotropin releasing hormone. Gen. Comp. Endocrinol., 62:202-209.

Yamashita, S., and S. Melmed (1986) Insulin-like growth factor I action on rat anterior pituitary cells: Suppression of growth hormone secretion and messenger ribonucleic acid levels. Endocrinology, 118:176-182. 